\title{
RISK FACTORS THAT MAY SIGNIFY A PROPENSITY TO THE USE OF DRUGS IN STUDENTS AT A PUBLIC UNIVERSITY
}

\author{
Meire Luci da Silva ${ }^{1}$, Nathalia M. R. dos Santos ${ }^{1}$, Viviani Barnabée ${ }^{2}$ Vitor E. Valenti ${ }^{3}$
}

\begin{abstract}
Introduction: We sought to evaluate the risk factors that may increase the propensity to use licit and illicit drugs among students at a public university. Methods: The project involved students $(n=268)$ enrolled in the first and fourth years of courses in the areas of the social and biological sciences at a public university. Data collection was conducted by means of self-administered, semistructured questionnaires, based on such standardized assessment instruments as Audit, Assist, Cage and Duse. Collected data were analyzed quantitatively by calculating the percentages and evaluating the data in terms of categories of risk, classifying them by age, gender, religion, schooling, use (before or after entering university) and contexts of use. By means of this survey the researchers were able to correlate the use of drugs to the risk factors that might increase the students' propensity to use these substances. Results: The results revealed a high proportion of current drug-using students, but showed no significant differences between the first and fourth year students as regards contexts of use. However, $67 \%$ of students regarded the university environment as encouraging the use of drugs. Students pointed to such major risk factors as friends' and fellow-students' influence, university parties, excessive curiosity and desire to experiment. Conclusion: Due to the high rate of drug use among university students, by the determination of the risk factors related to the university environment and also knowing that the process of addiction is one of growing chemical dependence, the importance of the development and implementation of public health policies at all levels, especially in terms of approaches and specific interventions addressing this population, should be noted.
\end{abstract}

Key words: psychoactive substance abuse, college students, risks factors

\section{INTRODUCTION}

Behavioral habits significantly influences students1, 2. Chemical dependence is a set of psychophysiological phenomena that develop with repeated substance use, classified in the International Code of Diseases (ICD-10) as mental and behavioral disorders due to use of psychoactive substances ${ }^{3}$.

Stamm and Bressan ${ }^{4}$ reported that during adolescence, when young people face their high school or higher education, they are motivated to experiment with alcohol and drug use. Wagner and Andrade $^{5}$ investigated drugs used by students of the University of São Paulo and found that 38\% had used illicit drugs at some time in their lives, $26.3 \%$ during the last 12 months and $18.9 \%$ within the last thirty days.
According to the Brazilian Observatory of Drug Information ${ }^{6}, 86.2 \%$ of college students reported having used alcohol at least once in their lives, the highest consumption being registered in public universities where $46.7 \%$ of students reported having used tobacco at least once in their lives and 58\% reported the use of two or more drugs. The data from this same study reveal a more pronounced consumption of licit and illicit drugs by the university population than by the general population as also with respect to the risk of this behavior to their lives.

Carvalho et al. ${ }^{7}$, based on the results of a study conducted with students of three health courses in the state of São Paulo, found that the situations in which the students consumed more drugs were related to the university environment. Chiapetti and Serbena ${ }^{8}$ who studied students of the medical school of Paulista State University (UNESP)

1 Department of Physical Therapy and Occupational Therapy.

2 Research at Harvard School of Public Health, Boston, MA, USA.

3 Department of Speech Language and Hearing Therapy, Faculty of Philosophy and Sciences, UNESP, Marília, SP, Brazil. Corresponding Author: meire@marilia.unesp.br

Suggested citation: da Silva ML, et al. Risk factors that may signify a propensity to the use of drugs in students at a public university. Journal of Human Growth and Development 2013; 23(3): 346-351

Manuscript submitted Mar 16 2013, accepted for publication Jul 202013. 
also noted the great influence exercised by university life regarding drug use on the part of students.

According to Pedrosa et al. ${ }^{9}$, the substance most commonly used by young people in Brazil is alcohol, followed by tobacco, cannabis and stimulants, which encourages them to take other substances which increase risk, thus highlighting the need for awareness and prevention programs addressed to youth.

Heavy consumption of psychoactive substances is associated with various factors that may pose risks both to the students themselves and to the society of which they are a part; it is therefore important to pay special attention to the motivation giving rise to the early use of these substances, since this can prevent the cases' becoming worse, in the light of the fact that opportunities for treatment in these cases are few ${ }^{10}$.

It was the high consumption rates of both licit and illicit drugs in Brazilian universities and the serious consequences of their use that awakened the authors' interest in the possibility of conducting a study of these groups, with a view to presenting a proposal for the prevention and treatment of the population concerned. The aim of this study was, therefore, to evaluate the risk factors that can induce public university students to use drugs.

\section{METHODS}

\section{Study population}

This is a descriptive populational study undertaken between March 2012 and October 2012. A total of 268 students enrolled in the first and fourth degrees of all the undergraduate courses of the Faculty of Philosophy and Sciences, UNESP, Marilia were investigated. The inclusion criterion was that the participants should be enrolled in and attend the $1^{\text {st }}$ and $4^{\text {th }}$ years of courses in the areas of Social and Biological Sciences of the Faculty of Philosophy and Sciences at Paulista State University. Excluded from the study were those students who responded to the questionnaire that they had never used drugs.

\section{Data collection}

A self-administered questionnaire on risk factors that might lead to the use of legal and/or illegal drugs, based on previously validated instruments such as AUDIT, ASSIST, CAGE and DUSI, was developed and applied. The questionnaire consists of questions related to the risk factors that lead to the consumption and abuse of drugs, the place of their use, the companions involved, the mood before the drug was taken and the reasons for its use. The study was approved by the Ethics in Research Committee of the Faculty of Philosophy and Science of Paulista State University (UNESP), under protocol no. 0443/2012.

The questionnaire was applied and the informed consent form signed and handed in during a lecture period of the $1^{\text {st }}$ and $4^{\text {th }}$ years of courses in the areas of Social and Biological Sciences of the Faculty of Philosophy and Science at Paulista State University (UNESP), Marília. It was applied to students of nine courses: Archival Sciences, Library Science, Social Sciences, Philosophy, Physiotherapy, Speech Language and Hearing Therapy, Education, International Relations and Occupational Therapy. After answering the questionnaire, the respondent deposited it in an urn, thus ensuring his/her anonymity. All the students signed the informed consent form and received a copy of it.

\section{Data analysis}

The data collected were analyzed quantitatively by calculated percentage and the results were interpreted and plotted for better visualization of the results.

\section{RESULTS}

The sample consisted of 268 students, 183 $(68 \%)$ of whom, when their questionnaires were analyzed, were found to have answered affirmatively regarding drug use at some time in their lives, the other 85 (32\%) denied ever having used drugs. The average age of the 183 students who had used drugs at least once in their lifetime was 22.8 years (SD \pm 2.97).

As for the gender of the students who had used some drug at least once in their lifetime, 135 (74\%) were female. Whereas among the first-year students, 60 (71\%) were female and 24 (29\%) male, in the $4^{\text {th }}$ year, 75 (76\%) were female and 24 (24\%) male.

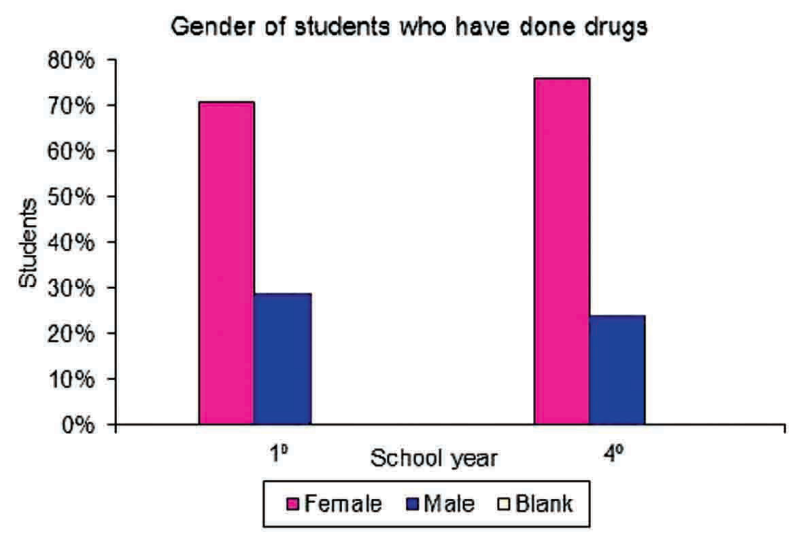

Figure 1: Percentage distribution of the gender of the participants who have used drugs at least once in life, separated by school year.

Of the total sample student population, 139 were in their $1^{\text {st }}$ year - of whom around $80(59 \%)$ had used drugs at least once in their lives and 129 were in their $4^{\text {th }}$ year - of whom 101 (78\%) had responded similarly (Figure 2 ). A higher incidence of drug use at least once in life was observed among the $4^{\text {th }}$ year students. 


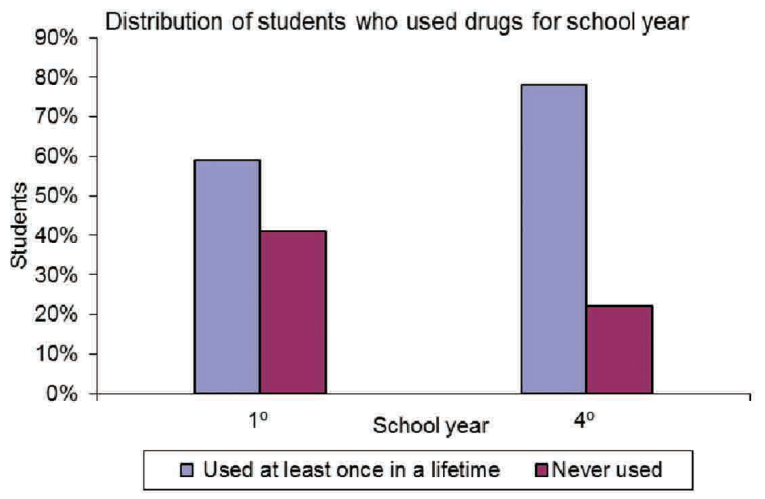

Figure 2: Percentage distribution of university students who used drugs at least once in their lifetime, according to school year.

Of the 183 participants who had used drugs at least once in their lives, $150(82 \%)$ had done so before entering college ( $84 \%$ of those in their $1^{\text {st }}$ year and $80 \%$ of $4^{\text {th }}$ year students) and $33(18 \%)$ had used it only after entering university (16\% of those in their $1^{\text {st }}$ year and $20 \%$ of $4^{\text {th }}$ year students). (Figure 3)

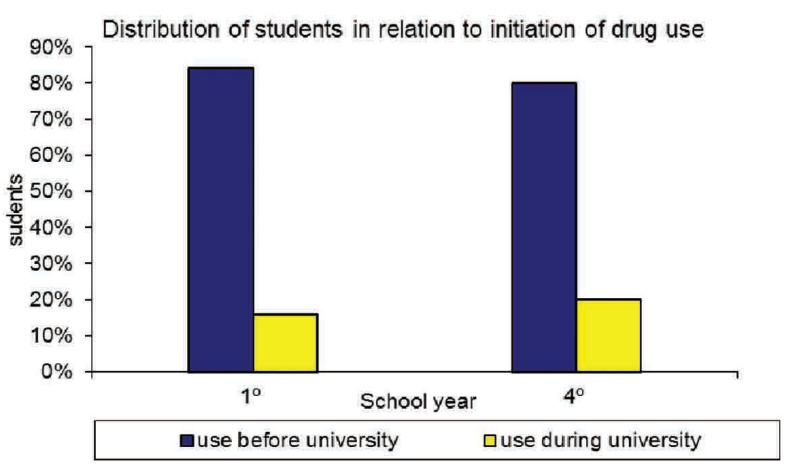

Figure 3: Percentage distribution of students who used any drugs before and after enter university, separated by school year.

In regard to the religion of the participants who had used drugs at least once in their lives, 49 $(60 \%)$ of the first-year students have some religion but $32(39 \%)$ do not. In relation to fourth-year students, $68(67 \%)$ were religious but 33 (33\%) were not. (Figure 4)

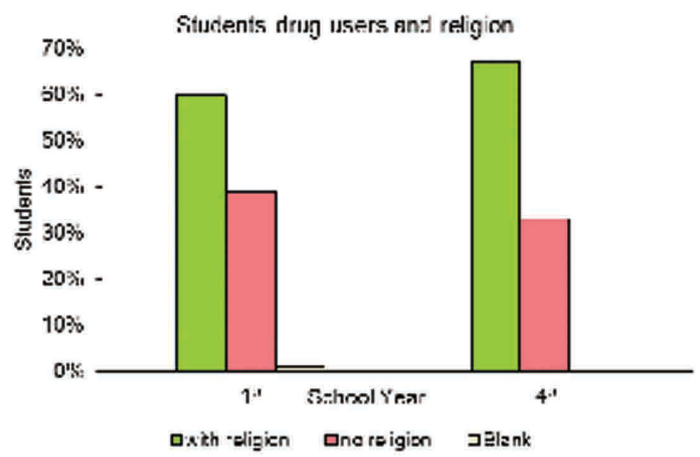

Figure 4: Percentage distribution of students who have used drugs, over whether or not religion, separated by school year.
As regards their residential arrangements, of the first-year students who had used some drug at least once in their lives, 35 (43\%) live with other students, $22(27 \%)$ live with their parents, 15 $(18 \%)$ live alone, $6(7 \%)$ live in public housing (paid for by the government) and 4 (5\%) did not answer. Among the fourth-year students, the respective numbers and percentages are: 58 (57\%), 23 (23\%), $18(18 \%), 2(2 \%)$ and $0 \%$. (Figure 5 )

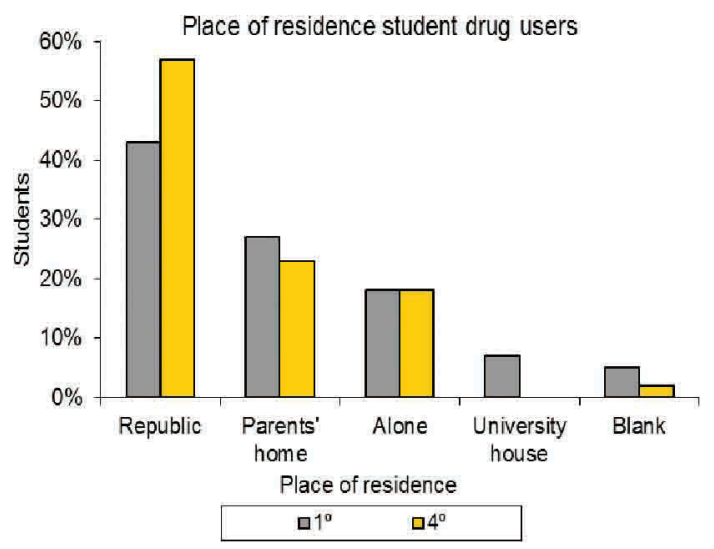

Figure 5: Percentage distribution of students live where they used drugs at least once in life, separated by school year.

In relation to companions during drug consumption, it was found that among the firstyear students, $38(62 \%)$ reported using it with friends and college roommates, $12(20 \%)$ reported using it with other drug users, $6(10 \%)$ used it alone and $5(8 \%)$ used it with their families. (Figure 6$)$

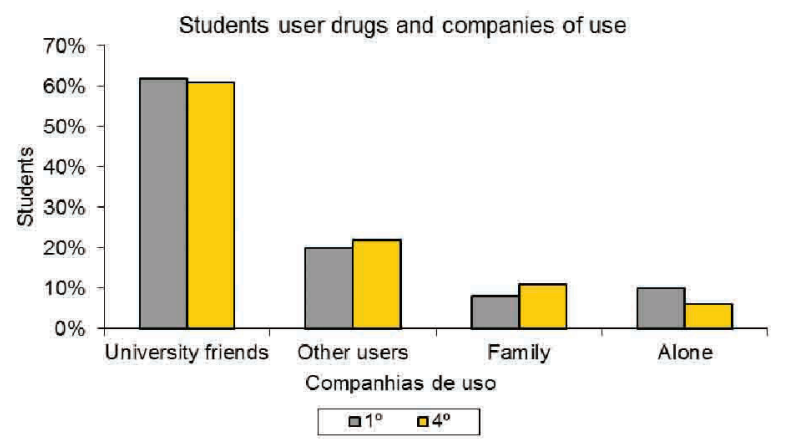

Figure 6: Percentage distribution of companies use most frequently in relation to students who still use any drugs, separated by school year.

Among the reasons given for their initial experience with drugs, 27 (51\%) of the first-year students quoted curiosity, followed by $7(13 \%)$ who reported the influence of friends, 5 ( $9 \%$ ) emotional problems, 1 (2\%) difficulty in relating and $13(25 \%)$ mentioned other causes. Among the fourth-year students who still use drugs, 43 gave curiosity as the reason, $26(26 \%)$ the influence of friends, 9 ( $9 \%)$ emotional problems, $6(6 \%)$ difficulty in relationships, 1 (1\%) family problems, 1 (1\%) 
financial problems, $1(1 \%)$ difficulties in sexual relationships and 13 (13\%) reported other causes. (Figure 7)

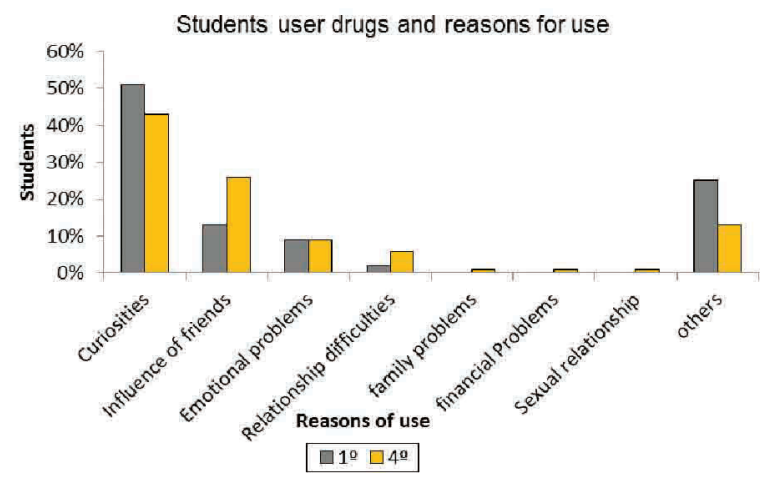

Figure 7: Percentage distribution of reasons for drug use by students who still used drugs, divided by school year.

We also investigated the places of drug use among students who still use them, the most commonly cited by first-year students being university parties with 41 (53\%) of the cases, followed by their homes with $19(25 \%), 10(13 \%)$ at college, $6(8 \%)$ in restaurants and $1(1 \%)$ in a bar. So also with the fourth-year students: 63 (59\%) reported consuming them at university parties, 25 $(23 \%)$ at home, $8(7 \%)$ on the street, $5(5 \%)$ at college and $6(6 \%)$ in bars and restaurants.

(Figure 8)

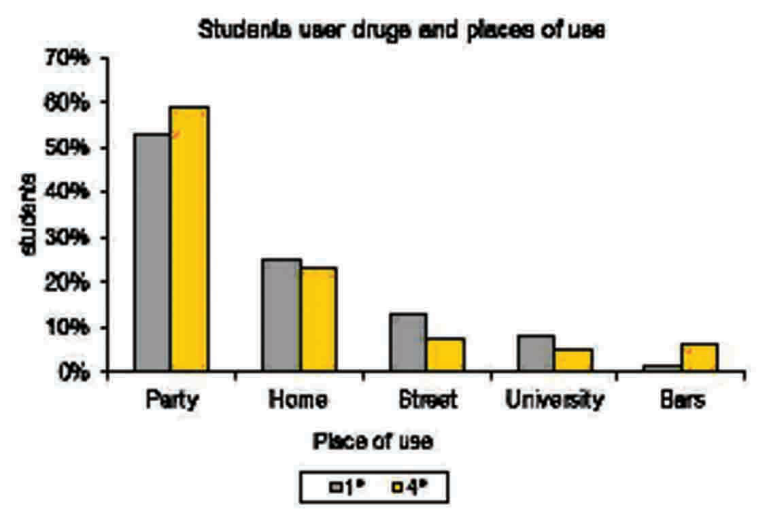

Figure 8: Percentage distribution of the most frequent use in relation to students who still make use of some type of drug, divided by school year.

Among students who continue to use drugs, we also investigated their mood before they use them. Among the first-year students, 35 (58\%) said their mood is one of joy, followed by $7(11 \%)$ who reported stress, $7(11 \%)$ euphoria, 5 ( $8 \%)$ depression, 4 (7\%) tiredness and 3 (5\%) worry. Among fourth-year students who still use some drug, 54 (52\%) quoted joy, $16(16 \%)$ stress, 13 $(13 \%)$ tiredness, $9(8 \%)$ depression and $6(6 \%)$ euphoria. (Figure 9)

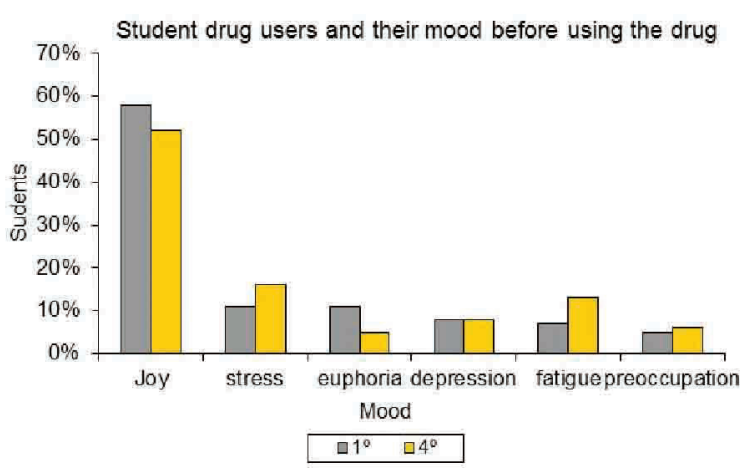

Figure 9: Percentage distribution of mood states before use the drug, divided by school year.

We also put the question as to whether the academic environment is seen as conducive to the use of drugs to the 183 study participants (both those who had only used them once in their lifetime and those who continue to use them). Of that total, $122(67 \%)$ students believe that the university environment favors the use of drugs, 47 (57\%) of them being in their first-year and 75 (74\%) in their fourth, while $55(30 \%)$ believe that the university environment is not a factor conducive to drug use, $31(38 \%)$ of them being in their first year and 24 $(24 \%)$ in their fourth. Six (3\%) did not respond. (Figure 10)

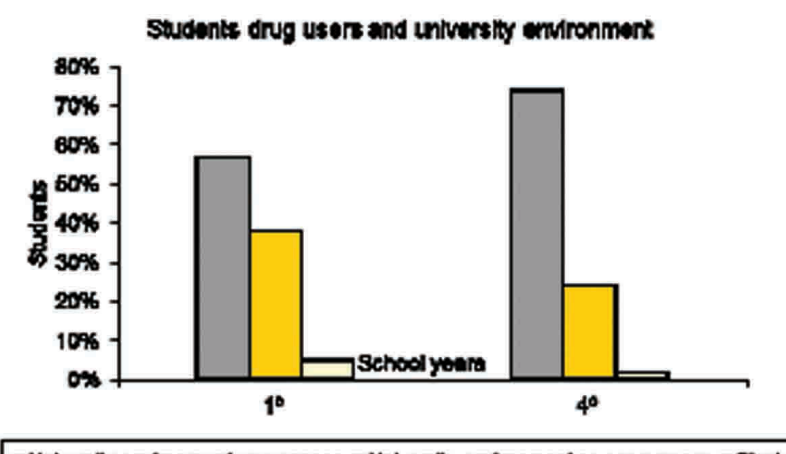

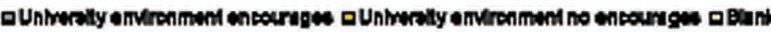

Figure 10: Percentage distribution of students who believe that the university environment is a stimulant or not to use drugs than those who have used some time in life, divided by school year.

\section{DISCUSSION}

We evaluated 268 students of the $1^{\text {st }}$ and $4^{\text {th }}$ years of all UNESP-Marilia's courses. Among them, $183(68 \%)$ had made use of some drug at least once in their lifetime while 85 (32\%) had never used any, thus corroborating the results of the research undertaken by Stamm and Bressan ${ }^{4}$. The results showed that most students had used some type of drug before entering college and it is believed that the first use may have occurred at parties and family gatherings, since alcohol is part of the culture of the country and is always present at parties, as is observed in the study mentioned ${ }^{4}$. 
Among students who had used some drug once in their lifetime, a high rate $(74 \%)$ of use among women was observed, corroborating the results reported by Stamm and Bressan ${ }^{4}$, who reported a high level of alcohol intake by women, and Wagner et al. ${ }^{11}$, who observed a significant increase in drug use by women.

The results of this study showed that most students $(60 \%$ of those in their first year and $67 \%$ of those in their fourth) who had used a drug at some time in their life were adepts of some religion, so the lack of religious belief is not to be identified as a significant risk factor, thus supporting the results of the study of Wagner et al. ${ }^{11}$

It was found that most students who used drugs at least once in their lives reside with others students, corroborating the results of the study undertaken by Queiroz ${ }^{12}$. In public universities, students usually come from other cities, live away from their families and more likely in the company of friends, which may be another indicator for the high incidence of drug use, due to the sensation of freedom and lack of rules or limits. In agreement with Chiapetti and Serbena ${ }^{8}$, the risk of drug use may increase when young people live at a distance from their families or when their parents are separated. Petroianu et al. ${ }^{13}$, in a study of medical students of the Faculty of Medicine of the Federal University de Minas Gerais (UFMG) report that students who live with their parents consume less licit and/or illicit drugs than do those who live away from home.

Of all the students who had used drugs at least once in their lives, we analyzed the number of those who still continue to use some kind of drug: $144(79 \%)$ still use them and 39 (21\%) no longer do so. Of that total, $56(68 \%)$ are in their first year and $88(87 \%)$ in their fourth.

There was a high prevalence of students who continue to make use of some kind of drug, the incidence being higher among fourth than among first year students.

As regards companionship in the use of drugs: there is a high prevalence of drug use in the company of friends and college roommates - which corroborates the results presented by Chiapetti \& Serbena ${ }^{8}$ who state that college students enjoy easy access to alcohol, that this is part of their social relationship and that it leads, therefore, to the association with friends and colleagues who are also users. They also comment on the role played by the media in the dissemination of these substances by presenting them as synonymous with power, financial success, sensuality, beauty and more. Teixeira et al. ${ }^{14}$ also point out that many students use drugs to socialize with other groups of students. Users considered the use of the drug a facilitator and promoter of social inclusion within the university environment.

That the places of use most frequently reported by the first and fourth year students were university parties is in agreement with the reports of previous studies ${ }^{7}, 15$. In a study published by
Andersson et al. ${ }^{16}$, students claimed that the use of alcohol made their parties livelier.

It is believed that the high incidence of continued drug use among fourth-year students is due to the increased contact with factors associated with consumption such as drug-using friends and university roommates and university parties, in respectively decreasing percentage terms.

The main motive for initial use cited by all the students investigated was curiosity, followed by the influence of friends, which corroborates the results of the study of Chiapetti \& Serbena ${ }^{8}$. The participants also had the option of specifying alternative motives and cited: desire, happiness, interest, pleasure and social use.

Joy was the mood most frequently described by the students ( $58 \%$ of those in their first year and $52 \%$ of those in their fourth) prior to using the drug. In research projects conducted by Chiapetti \& Serbena ${ }^{6}$ and Paduani et al. ${ }^{15}$, participants reported stress as the state of mind more frequently experienced than in the study that classified it in second place. However, along with other factors that were highlighted in this study, friends and college roommates used graduation and other college parties and local use naturally mood is joy, confirmed the university environment is an exciting place for drug use.

We observe that most of the students who have used drugs live with other students, which points to the place of residence as a risk factor for both first and fourth year students.

This research project sought to identify the major risk factors that might induce students to use drugs, and the results found were that over half $(68 \%)$ of the students surveyed have used drugs at least once in their lifetime and that $79 \%$ of them continue to use them, the highest incidence being found among fourth-year students, $87 \%$ of whom had already used some drug in their first year and $68 \%$ of whom continue to consume some such substance.

As to the situations in which drugs are used, no significant differences were found when the responses of first and fourth year students were compared, but it was observed that the main risk factors mentioned by the students were friends and fellow-students, university parties, curiosity and joy. The results also showed that $67 \%$ of students $(57 \%$ in their first and $74 \%$ in their fourth-year) considered the university environment a place conducive to the use of drugs.

The reaction to the use of the questionnaire evidenced the reluctance and occasional refusal to participate in this project on the part of students, especially among those on the social science courses, because the subject matter is controversial and some students preferred not to expose their beliefs and behavior to scrutiny - which constitutes a limiting factor for the study.

We conclude that the risk factors investigated indicated emphasize that the 
permanent and/or continued use of drugs by students can be encouraged by the university environment. In the light of the results of this study and also because the addictive process is one of gradual installation, the importance of developing and implementing public health policies at all

\section{REFERENCES}

1. ORGANIZAÇÃO MUNDIAL DE SAÚDE. Classificação de transtornos mentais e de comportamento da CID 10. Descrições clínicas e diretrizes diagnósticas. Porto alegre: Artes médicas; 1993.

2. Stamm M, Bressan L. Consumo de álcool entre estudantes do curso de enfermagem de um município do oeste catarinense. Revista Ciência, Cuidado e Saúde 2007;3:319-324.

3. Wagner GA, Andrade AG. Uso de álcool, tabaco e outras drogas entre estudantes universitários brasileiros. Revista de Psiquiatria Clínica 2008; 35:48-54.

4. Observatório Brasileiro de Informações Sobre Drogas. Disponível em: <http:// www.obid.senad.gov.br/portais/OBID/ index.php>. Acesso em 23 de março de 2012.

5. Carvalho AMP, Cunningham J, Strike C, Brands B, Wright MGM. Normas percebidas por estudantes universitários de três carreiras, da área da saúde, sobre o uso de drogas entre seus pares. Revista Latino-Americana de Enfermagem 2009; 17:900-906.

6. Chiapetti N, Serbena CA. Uso de álcool, tabaco e drogas por estudantes da área de saúde de uma Universidade de Curitiba. Psicologia: Reflexão e Critica 2007; 20:303-313.

7. Pedrosa AAS, Camacho LAB, Passos SRL, Oliveira RVC. Consumo de álcool entre estudantes universitários. Caderno de Saúde Pública 2011; 27:1611-1621.

8. Pinho $\mathrm{PH}$, Oliveira MA, Almeida MM. A reabilitação psicossocial na atenção aos transtornos levels, especially with regard to approaches and specific interventions addressed to this population, should be emphasized. The deterioration of the cases concerned, which can often lead to poor academic performance and other serious social consequences, could thus be avoided.

associados ao consumo de álcool e outras drogas: uma estratégia possível? Revista de Psiquiatria Clínica 2008; 35:82-88.

9. Wagner GA, Stempliuk VA Zilberman M, Barroso LP, Andrade AG. Alcohol and drug use among university students: gender differences. Revista Brasileira de Psiquiatria 2007; 29:123-129.

10. Queiroz S. Fatores relacionados ao uso de drogas e condições de risco entre alunos de graduação da Universidade de São Paulo. 2000. 191 f. Tese (Doutorado) - Universidade de São Paulo, São Paulo, 2000.

11. Petroianu A, Reis DCF, Cunha BDS, Souza DM. Prevalência do consumo de álcool, tabaco e entorpecentes por estudantes de medicina da universidade federal de minas gerais. Revista da Associação Médica Brasileira 2010; 32: 568-571.

12. Teixeira RF, Souza RS, Buaiz V, Siqueira MM. Uso de substâncias psicoativas entre estudantes de odontologia da Universidade Federal do Espírito Santo. Ciência e Saúde Coletiva 2010; 15:655-662.

13. Paduani GF, Barbosa HA, Morais JCR, Pereira JCP, Almeida MF, Prado MM, Almeida NB, Ribeiro $M$. A. Consumo de álcool e fumo entre os estudantes da Faculdade de Medicina da Universidade Federal de Uberlândia. Revista Brasileira de Educação Médica 2008; 32:66-74.

14. Andersson A, Wiréhn $A B$, Olvander $C$, Ekman DS, Bendtsen P. Alcohol use among university students in Sweden measured by an electronic screening instrument. BCM Public Health 2009; 229:9. 